\title{
Alymphoid cystic thymic dysgenesis
}

INSERM

\section{Source}

INSERM. (1999). Orphanet: an online rare disease and orphan drug data base. Alymphoid cystic thymic dysgenesis. ORPHA:169095

Alymphoid cystic thymic dysgenesis is a rare, genetic, primary immunodeficiency due to a defect in adaptive immunity characterized by the triad of congenital athymia (resulting in severe T-cell immunodeficiency), cong enital alopecia totalis and nail dystrophy. Patients present neonatal or infantile-onset, severe, recurrent, life-threatening infections and low or absent circulating T cells. Additional features reported include erythroderma, lymphoadenopathy, diarrhea and failure to thrive. 